\title{
Attack Formation
}

\section{Colonel G. Upton Prior Late Commanding 2nd Battalion The Royal Scots}

To cite this article: Colonel G. Upton Prior Late Commanding 2nd Battalion The Royal Scots (1891) Attack Formation, Royal United Services Institution. Journal, 35:158, 345-366, DOI: $\underline{10.1080 / 03071849109417295}$

To link to this article: http://dx.doi.org/10.1080/03071849109417295

\section{曲 Published online: 11 Sep 2009.}

Submit your article to this journal $\pi$

\section{Џ Article views: 2}

Q View related articles $匚$ 
Wednesdas, Febraary 18, 1801.

Gexeral Sir C. P. BEAUCHAJIP.JWAIJER, K.C.B., VicePresident, in the Clair.

ATIACK FORJIATION.

By Colonel G. Urtox Prion, late Commanding 2nd Battalion The Rojal Scots.

\section{Part I.}

Ix discuesing the question of an attack formation, it is not possible to do so without intreducing into the argunent the formations in roguc at the present time, and this I renture to hope will be considered at good enough reason for the prominent way in which the attack formations laid down in tho present Field lexerciso aro mentioned. Though it will be scen that the criticisms are not favourable to the formations themselves, theg are to the excellent masims laid down in the Field Lsercise, on which thoso formations are based. Theso moxims will be found in the cliapter on Tactics of the Field Exercise, Part 6. Tho formations are only introduced as being the latest extant, and as the most convenient way of approaching a subject which, though looking simple, is really diflicult, justifying the remark of Clausewitz that "ererything in war is simple, but what is. simple is difficult."

$\Delta \mathrm{s}$ the Field Exercise is, $\mathrm{I}$ beliere, having a few alterations made. in it, and the attack formation was, I presume, bo looked upon as virtually dead, it will be for the public good if we use them as a lesson for any fnture formation, and the present scems a favourable opportunity for any discussion on the subject. I would desiro to say low much I nm indebted to the "Letters" on Infantry, Artillers, and Caralry, by H.S.H. Princo Kraft za Iohenlohe-Ingelingen, translated by Lient.-Colonel Walford, Rogal Artillery.

With these introductory remarks I will proceed with the argument.

The question of the formation most suitable for infantry to adopt when attacking lias always been of rital importance to the success of an army. This formation has erer been a rarsing one, depending chiefly on the great factor of the "arms of the day"; there were dense masses in Continental armies and rigid lines in the English with unrifed arrns, and a gradual shaking out of such formations into finer ones when these arms improred. As the Field Fixcrcise of 1890 justly remarks, "Normal tactical formations have a real absolute ralue, and when adapted to the configuration of the ground, and to the nature and condition of the troops, seldom fail to influenco 
favourably the issue of a contest." The Field Exercise also gives the conditions on which now-a-days all formations intended to be used by troops, attacking a disciplined and well-armed enemy should be based.

These conditions are :

(1.) Admit of the most efficacions fire at all times, and of its greatest derelopment at the decisire moment.

(2.) Present a difficult target to the enemy's fire.

(3.) Allow of the best use of any corer that can be adrantageously made use of.

(4.) Afford the greatest mobility at all times.

(5.) Admit readily of reinforcement.

(6.) Lend themselves to the maintenance of command.

One first duty" is to consider whether these conditions represent correctly and adequately the requirements of the present time.

Now eridently the main factor which has been kept in riew in framing them has been that of the arms of the day; Nos. 1, 2, 3, 4, 5 conditions all point to this.

But so quickly do changes occar that, cren since the aboro conditions were written, arms hare improred, and other factors besides arms hare arisen, which might nccessitato fresh conditions. These are:

lst. The tendency to employ cavalry in masses, a subject on which wo hare had the adrantage of a raluable lecture at Aldershot latels.

2nd. The invention of a smokeless and a possibly noiseless powder.

We must also recollect that in the Fnglish Arms there is always the posibility of fighting badly armed fanatics. This, however, is not a new factor.

We may take it then that the tro factors giren above, with that of the Arms of tho das, are tho three great factors regulating the conditions of any attack formation; and a safe, and I trust not a tedious, way of considering the question would be to treat each of these factors separately, seeing first, if any of them require new conditions, besides the six laid down in the Ficld Exercise; sccondly, to test the Field Exercise formation both with its own conditions and with any such new conditions if fonnd; and, thirdly, to frame an attack formation suitable to them.

Taking the factor of arms of the das, these are rifled artillery and the magazine small-bore rifle. The artillery is pretty much the same as it has been for the last few jears, and rery powerful, indeed, are the field guns, the only practical limit to their range being tho powers of rision. The small-bore magazine rifle is quite a new reapon, its speciality being a very flat trajectors with great powers of penetration.

Now, armed with a rillo like this, what sort of formation would it snit us to fire at? Eridently one with a good depth, in which there are a good many rows of troops behind one another, for then if a bad shot were made, it.would matter little if tho bullet went to the right or left of the man aimed at in the first row, and thus through 
gap in that row, becnuse, if the elovation were good, it would go on and hit someone in a row behind; whilst if the shot were a good one, it would hit. not only the man aimed at in the frst row, but, going through him, might hit someone in a row behind, as I am informed that the flat trajectory 303 bullet will go through six men or three horses. $\Lambda$ story given by Prineo Hohenlohe-Ingelfingen sliows the power even of the rifle the l'russians had in 1870; lie sass that at St. Prirat the glacis was in front of the rillage of Ste. Maric, which was rather advanced on the right flank; out of this village a flock of frightened sheep barst, crossing the front of the Prussians as they rere about 600 jards off; the Prussians thought from the dust the sheep raised that they were cavalrs, and shot every one of them. As ragards artillers, though its effect is not so important in an attack formation as elsewhere, because the nrtillery of the defence is generally silenced early, it is a well-known fact that it is the density of the formation which is the greatest canse of loss to troops ander its fire; the ground covered by the bursting of a shell being far grenter in depth than in width. Both these wcapons, then, which constitute the factor of arms of the day;, would indict frightful slaughter on troops drawn up in successive rows, and as such an eventuality does not scem to be sufficiently considered in the six conditions laid down in the Ficld Fxercise, we must add this condition to thern, viz.:-

When troops are under fire no two lines should advance together within 200 yards of each other.

Let us now consider the second factor of the tendency to emplos caralry in masses.

'The massing of caralry at peace manceurres has been largely carried out of late bj Continental nations, especially by Germany, Russia, France, Itals, aud Austria all following in the same line, and even we ourselres have dared to spend 3,000l. on such mancuvres, and are thinking of having some rnore in three jenr's' time, if we then hare the mones. Whether this cliange in the handling of cavaliry has a strategical or a tactical object, it is diflicult to say, probably the former chiefly. Now, as the German cavalry in 1870, departing from the custom of war in those days in like cases of sticking close to their infantrs, suddenly dereloped the new rôle of boldly adrancing miles in front, and spreading orer a large aren of countrs, thes secaring to their own side the greatest strategical advantages, why should not the Germans, or any cavalry in the next great war, suddenly develop some trnit hitherto looked upon as absurd, which might give to their side great tactical adrantages?

The Germans commenced such tactical action on tho 16th Augast, 1870 , at the battle of Vionville-Mars-la-Tour, when, having only one A'rmy Corps, their IIIrd, against three French Corps, tho IIIrd, IVth, and VIth, they were obliged to use some 8,000 caralry as second lino to their infantry, until infantry reinforcements arrired; the cavalry acting as second line from 10 to 12 o'clock in the morning; and later on, the most of them, making with others a total of 78 squadrons, were moved to the Prassian left, to check the 
advance of the IIIrd and IVth French Army Corps, who were making a flank movement against tho Prussian left. Masses of cavalry wero also nsed by the French three times, viz., at Wörth, MTars-la-'lour, and Sedan.

If it is found, then, that, despite the powers of rifled artillery and magazine small-bore rilles, a cavalry leader, making uso of the grond and seizing on occasions when troops are exlanusted, dispirited, or without ammunition, should hurl his masses against them, we should have a great tactical adrantage for the side on which are such dashing cavalry. And it must be recollected that the caralry of the defence hare a much better opportunity of charging during an action than those of the attack, because they lnow the ground beforehand, can be placed ready waiting, and they have not so far to go to get to a flank.

The following examples show what caralry hare done formerly in action.

In days gone by, many more victories were won by cavalry masses than in later days; thus, the battle of Rossbach was won entirely by cavalry.

In 1866, at the battle of Custozza, two Anstrian caralry brigades, strength about 2,500 men, charged two Italian dirisions, streugth about 20,000 men, breaking through the skirmishing line and squares and creating such a panic that these divisions were useless for the whole day; at 5 p.y. they charged the samo infantry again, and took 1,000 prisoners. And this was in a country move close than open, laving many trecs.

At the battle of Koeniggratz, a squadron of Prussian caralry sarprised a victorious Austrian battalion as it was advancing, and took the whole of them prisoners, some 600 men.

$\Lambda t$ the battle of Sedan, the dirisional caralrs of the Germans continually charged in indiridual squadrons, and patrolled and reconnoitred during the fight.

On the 16th August, 1870, at the battle of Vionrille-Mars-1n-Tour, General von $\Lambda$ lvensleben, wishing to gain time for the sixth division of the IIIrd Army Corps attacked by a rery superior French force, ordered Bredow's brigade, consisting of six squadrous, some 800 men only, to charge, and they rode down the first line of the infantry of tho whole corps, and then went on and cut down the teams and detachments of tho artillery, checking the entire corps for the whole day, and virtually saring the day.

The subject is a deeply engrossing caralry one, but in considering any attack formation we canuot enter further into it than to take it into our calculations as a possibility, aud as such to make our plạus beforehand agrinst it. Tho grent powers of the new rifle come to our assistance in this; we have both a rapidly-firing weapon and one which covers tho first 500 jards of ground without any chango of sights. And we must use these powers against this possibly new tactical action of cavalry. To take advantage of the rapid fire, we must hare as large a front as possible for any close formation (wo will call them here squares) against caralyy. Another adrantage of having 
large squares is that it brings the natural fears of the horse on onr side; for horses are not machincs besond a certain point,-and though they nay be driven over infantry scattered in groups, or even orer small sectional squares, jet they will not face any formation with a front big cnough to show a good fringe of bisonets, because thes can see that a long way off, eren if they are going at a gallop; and they will then naturally open out, and go ronnd the flanks, whilst the few who are driven into tho square will be absorbed by it. Again, as caralyy never charge in a single line, but with a second and third on the flanks of the first, small squares, thongh ther may resist the first cavaliy line, would probably be broken by the flanking oues. Therefore, no square shonld be smaller than that of a company.

'To take advantage of the power of the flat trajectory, and thus cuable our men to tire at cavalry a long way off, we must hare a clear ficld of firc; therefore, we must take care that our men are not: in each other's was. This flat trajectory power disposes of the argument that largo squares would suffer from artillers tire. A smart infantry shonld not do so now, for, with snokeless powder, caralry would be secn a long way off; thes cannot now pretend to charge, stopping thrce or four liundred yards short, directly they hare got the inf:untry into squares; the infantry would now fire at them, and they would lose as wany men from the infantry fire as the infantry would lose from the artillery. If the caralry carry out the charge, their artillery uust stop firing when the cavalry are within 400 rards of the square. A sinart infantry need not then form square till the last moment; it can lie down when formed, and it can open out directly the caralry commence to retire. It may be stated here that, in the campnign of 1870 , the greatest nnmber of cavalry charges against squares took place at Sedan, and were, as a rule, failures, though the French caralry rodo most gallanily. We thesefore obtain from this factor that "no squarc, meaning ang close formation, should be smaller than that of a company."

The third factor is smokeless porder, and its effect wonld seem to be as follows :-

(1.) 'The iufantry of the defence, through being ablo to open fire without being themselres seen, could often inflict. such sudden slaughter on the infautry of the attack as to render it liable to panic.

(2.) Both sides will not only be without the excitement caused by noise and smoke, but will bo ablo to see and hear most clearly all the Lorror's of the battlefield. The nerres of both sides, and especially those of the attack, will be much more highly tried than they were in the old days. Fire discipliue will be more likely to go to pieces; troops will not aim, but will firo anyhow, cven without patting their rifles to their shoulders, or up into the nir as if they were firing a feu de joie. Prince Hohenlohe-Ingelfingen remarks, "How difficult it is in the excitement of battlo to teach infautry to attend to rords of command and cautions, as to which target, with what sight, and with what description of fire they are to act; and, morcover, to accustom them to cense firing when thes have expended tho stated 
number of rounds! It is asking rery mach of a man who is under the enemy's fire to expect him to cease fire in return for a ccrtain space of time. A fire which has once commenced gets easily out of land unless an 'iron discipline' prevails. It is so natural, so haman, that the soldier should find comfort in the noise which his rattling rifle makes. 'Tho less $n$ man is trained the moro he is iuclined to shoot up his plucl.:"

Consequently, one effect of smokeless powder will be to mako the men lean moro than erer on their Officers, or, in other words, discipline, and the strictest discipline, is more than ever necessary.

- No. 6 condition of the Field Exerciso partially provides for this, but we might add the following words to it:- "So as to ensure the strictest discipline being maintained."

Summarizing tho results so far, we haro the aboro addition to No. 6 condition of the Field Fxercise, and two new conditions, viz. :-

From the factor of the arms of the das, "No two lines to advance together within 200 fards of each other nnder fire;" and-

From the factor of cavalry in masses, "No closo formation to be formed against cavalry smaller than that of a company," if it can bo aroided.

Let us now test the attack formation laid down in the Ficld Exercise by these conditions; and in doing so, let us assume that in considering any attack formation, the case of a battalion acting by itself be thought exceptional, and be treated as such; and the argument be based on tho broader unit of a brigade, because no smaller force than a brigade could be detailed to act with any hope of success against a point chosen as an oljectire in a hostilo position. Plate 37 of the Field Exercise, being seemingly a typical brigade formation of attack, is taken as the representative one, the battalion in its first line being distributed as laid down in Plate 36 of the Field Exercise; this formation is shown in the wall diagrams coloured red. There aro two, one showing the attack at 1,000 Jards from the position; the other at 450 yards. . For tho sake of comparison, Diagrams 1 and 2 are taken at the same distances; whilst Diagram 3, Plate 3, shows the attack at 50 yards from the position.

Procecding to test this formation, and taking the conditions one by one, No. 1 condition wo can see, by simply looking at tho diagram, is fairly falfilled.

No. 2 condition, "formations should present a dificult target to tho cnemy's fre," may bo considered with condition No. 7, "no two lines to stand up together within 200 yards of one another under fire."

$A$ mere look at the diagram shows that they are not fulfilled, as even at 1,000 yards the target offered to tho enemy is a rery casy one, whilst at 450 fards it is mach moro so, especially to aimcd infantry fire, as the mass gets denser and denser tho nearer they approach the position. Not ouly are there two lines of men behind onc another; but probably half-a.dozen, because, besides tho firing 
line, the supports, nnd the reserve of the first line, we haro a number of men continually running $a p$ between the supports and the firing line, and as the advance of theso last men is at the will of many different leaders, it is likely to be very irregular.

No. 3 condition to "allow of the best use of any cover that can be advantageously made use of," is fairly falfilled.

No. 4 condition, of "affording the greatest mebility at all times," is not fulfilled, if the term is applied, as it is presnmed, to the mobility of formed bodies, for the men are so scattered in small sections and commands, that it would be very difficult to get them together for any combined action. And this point is particalarly important in a field freo of smoke, when not only the Captains and the Coloncls can see, but eren the General of the brigade, division, or army corps. The General may, at any minute, receive information, perhaps from a balloon in rear, cnabling him to make determinations and decisions. For instance, in tho caso of a counter-attack, or of orders for the use of machine-guns, or in the case of his being obliged to nse his infantry to help the artillery advance, or his artillery to help the infantry advauce, or eren of a retirement or rererse. The Colonels again, in the firing line, may have to giro orders about an attack by caralry, or to mako certain companies lio down to let artillery fre orer their beads. The Majors and Captains may Lavo orders about the "Cone of fire," \&c., \&c. For any such special objects requiring the power of using commands quichly, tho men must be well in hand.

No. 5 condition is to "admit readily of reinforcement." Now the plan adopted in the Field Exercise may be suitablo for a battalion, but hardly seems so for a large body liko a division or army corps, where there rould be many battalions in a line, as it would interfere greatly with the regularity of the adrance. T'aking cren the case of a brigade, it will bo noticed that nntil the supports are absorbed in the firing line there are no less than sixtecu points from which reinforcements keep on arriring in the firing line; and after this lias occurred, there are eight points, viz., one from cach compang in the reserres. Now, everyonc here will have often noticed how tho arrival of one mnn, with a wrong interral in a shirmishing line, will make the whole line ware. $\Lambda$ regular stendy incline does not nutter much, but it is when the wares are first one way and then the other that irregularity is caused. In the present case we hare numbers of men continually arriving from sixteen points, which, with irregularity of ground and losses, must cause waves both wass. Of course this Fill be nentralized to a certain extent by each company advancing as it does by its centre, but not entirely. When tho reserves commenco reinforcing the firing line, wo may hare a half-company of one company and a section of another in support side by side.!

No. 6 condition, that "formations should lend themselves to the maintenance of command, so as to ensure the strictest discipline being maintained," is a most important condition and worth going into.

The first rords that come across our mind are those of paragraph 15, 
section 7, of the Queen's Regnlations, under the heading of "Chain of Responsibility," which reads as follows:- "Nothing more essentially tends to the maintenance of regularity and good order than that system or chain of responsibility, which should extend from the highest to the lowest grade." No words could more clearly conrey the conditions necessary for the maintenance of discipline, and the experience of ages has proved their correctness. Is there a proper. chnin of responsibility amongst troops extended liko these? Do the Officers who have commanded in peace, and whom the nen are accustomed to obos, cxercise that control in the fight during its whole stage that they ought to? Do they hare their own men collected under their own command? Does the General command his brigade, the Colonel his battalion, and the Captain his company? Certaiuly not, for from the very moment the battalion breaks into attack formation, the commauds are scattered, going from the hauds of their natural leaders, the Colonel and the Captain, into those of the section leaders. The General would find it very haril to get his brigado to carrs ont any order quickly; the Colonel would be similarly situated; whilst the Captain has his company in three detachments with a front of 100 paces and a depth of 200 . The chain of responsibility does not extend down; it is broken. I ater on, when the battalion gets to within about 400 sards of the position; the supports, if one happens to reinforeo more than another, might for some time consist of balf companies of different companies. There is too much dispersion and mixing up even for pence, and the followiug exnmples show what it might be in war.

At the battle of Vionrille-MIars-la-'Tour, men were so mixed up that the only unit of command preserved at the end of the day was a regiment (viz., a brigado with us). At the battle of Grarelotte and St. Privat, almost all tho regiments were fighting sido by side in compact masses; at the farm of St. Hubert alone, 43 companies belonging to eight different regiments were crowded together. Now as a German company numbers probibly some 170 men after they have been in the field a few days, the number of English companies, under tho same circumstances, probably about 60 men each, that this would make is open to calculation. Some writers quote the abore example as an argument in farour of the loosest formation, but the fact seems moro as if the Prussians had rushed from the extreme of a rery close formation to the opposite estreme of too loose a one. It is seemingly a fair conclusion then that tho dispersion of command in such a formation as that of the Ficld Ixerciso cannot bo conducire to control orer individual men in a monjent of panic, or when nerres aro unstrung, or to that "iron fire discipline" we hare shown as being so necessary.

No. 8 condition is that "no square smaller than that of a company" is to be formed. This condition could not be fulfilled, as, owini to the distance of the firing line from the supports, company squares could not be formel quick cnough. Looking at the red dingram, the forma. tion is seemingly such as to tempt the most peacefully dispositioned caralrs leader to attack. Not only are the men, from their entry into 
the first zone, scattered abont in bodies too small to be plainly seen a good distance off by horses rapidly adrancing, but they an so placed in each other's way and in the way of the bodies behind, that if any fired they would be as likely to shoot each other as the cavalrs. Caralry miglit safely charge into such a mass of small units withont much danger to themselres, and with a rer'y good chance of onting up the small bodies and creating a panic.

Summarizing the results, the Field Exercise formation falfils No8. 1 and 3 conditions, partially fulfils No. 5, and does not fulfil Nos. $2,4,6,7$, and 8 .

There is another point in the formation which would haro a most important bearing during an action, and which has not been touched apon $50^{\circ}$, and that is the plan laid down for the direction of the advance. Though there is a "company of direction" to regulate the pace, yet there is no ono directing point; each company marches by its own centre on an objectivo point of its own; thus, without entering into the larger question of an Army Corps or Division, we fad that in a brigade we have eigbt different lines of advance before the reserres have reinfored tho supports, and when all the reserves are absorbed in the firing line we should have sixteen lines of adrance, viz., one for cach company. 'Taking eight lines even, it is not likely that these eight lines of adrance have been exactly parallel originally, but supposing they were, and the ground like a billiard table, with well-marked objective points on which to march, the manonrre would not by any means be an easy one. But when the adrance is to take place under fire, orer gronnd probably undulating, in crossing which the files of direction and N.C.O.'s superrising them must occasionally loso sight of their objective points, to say nothing of the confusion caused by obstacles, as ditches, small spinneys, hedges, or perhaps foggy weather, and of the advance being continually interrapted bj losses, and the arrival of reinforcements in the firing line, I think enough has becn said to show that the chances of the eight lines of direction either crossing orgoing away from cach other, with the consequent jamming or orercxtending of men, is more than great, it is quito impracticable.

Another criticism of a practical natare, seeming worthy of notiec, is that the present attack formation is too intricate for an army composed of such hetirogeneous materials as ours. It must bo recollected that it is the attack formation not only of the Regalar Army but also of the Militia, the Volunteers, and of the Indian Army; and that the Reserve Forces have few clances of practising it, whilst in the Indian Army there are a very small number of British officers present with the battalion. From the first moment when the companies move forward, and have to divido the front, "taking up such position as will enable them, when their two sections are extended to three paces interval, to cover the same front as the first line would occupy were it deployed into line," to the later periods of the attack, when tho bringing up of reinforcements accurately into the gaps of the firing line, which with the least uudulations; sprinkling of brushrood, or foggy weather, are most difficalt to sec, the leading

VOL. IXIV. 2 y 
of the micn requires Officcrs and: N.C.O.'s of some experience: And this wonld be felt more in war, when any day the formation might have to be taken up most quickly on unexpectedly falling in with an enemy, as in 1870 at the battles of Spicheren and Wörth. A simpler formation, and one more approaching the Iine with skirmishers in front, the formation so loved by British troops, in which they havo performed such gallant deeds, and which we know suit their temperament, would I think be better could we get it.

\section{PART II.}

The formation submitted to the meeting attempts to carry out this idea, and at the same time to fulfil the conditions of the Field Exercise, and the new ones we have framed; it is not submitted in any way as being the best attack formation; the only part of it that has been tried practically is the "Adrance by ranks," and a field test is after all the only real one. Scomingly any attack on these lines will keep the men more than under the control of the Officers, especially of the senior Officers, and will combine discipline, solidity, and mobility with individual action.

Before entering into the formation let the following be permitted :-

(1.) When under fire, let tho proper position of every man be, as now, lying down; this is not to mean creeping or crawling about.

(2.) Let there be no proper front rank nor rear rank; let the term "front rank" mean the rank that happens at any time to be in front, and the term "rear rank" the one that happens to be in the rear. Thus the ranks may change at any minate by the rear rank going through. gaps in the front, and the rear rank becomes the front rank, and so on.

(3.) Advance without firing by ranks.

When men are lying down under artillery fire, and are required to adrance without fring, it will be conducted thas: The Company Commander, Major or Captain, we will call hin Captain, will blow his whistle, and, according to the nature of the tire, either donble or ran through both ranks, the men of the front rank tarning orer on their left sides on the sound of his whistle. The Captain will adrance not more than forty yards, followed closely by the rear rank, who will cach pass on tho right of his front muk man. On the Oaptain throwing himself on the ground, the rank following him will pass him and throw themselves down about fire yards in front of him, so as to allow room for tho other ranks to lio down between them and tho Captain. This will be the signel for the rank left lying down, and for the snpernumerary rank, who will both be watching, to rise withont orders, and, cither doubling or yushing forward, to lie down behind the rank that has followed the Captain. Thus only one rank is ander fire at the same time; and ono bullet will not kill two. men. The advance will be continued in this manner. If the fire permits it, the double will always be used and not the rush. If it is 
thought preferable, the rear rank instead of lying down exactly bebind the front rank can lie a little to one side behind the intervals.

\section{Adrance Firing.}

(4.) When men lying down under fire are to advance firing, the ihen front rank only will fire, the then rear rank will not fire. "Tho Captain will give the command for as many men to fire as he thinks pecessary; the command will be given to the front rank by the section leaders in tho ordinary way. Directly it is is carried out the Captain will blow his whistle, run through both ranks followed by the rank which has not fired; and so on as in tho adrance by ranks without firing.

Thus the fire of the rank which fires covers the advance of the rank which has to rush to the front; and even if there is no smoko the bullets disturb the nim of an enemy just as the men advance. The reason of waiting for the rnaks to get together beforo firing is that it gires the Captain about half a minuto to consider his next order, it gives the rank which has just rushed a little time to get their wind beforo firing, and it brings up the supernumerary rank to command the next firing. Tactically, the advantage of an advance by ranks is that it keeps the men in two ranks, and thus enables the company to be kept well ander the control of the Captain and section leaders during the whole adrance. It also leares no doubt as to which part of the company is to advance, as in each adrance the whole rank has to go. Whon different portions are detailed at each advance, thero is often confusion and donbt as to who is to more.

\section{Form of Attack.}

In drawing out a Form of Attack, the first point is to fix tho positions of the four battalions composing the brigade. Let two battalions go into the First lino (see Plato 3, Diagram 1), one into tho Second, and one into the Third. The front of the Brigade will be determined by the front of the Second Iino in rank entire, because that is tho front with which we mean to assault tho position. Thus, in peace or kar it will be crer varying, depending on the number of men actually in the ranks. In peace-time, when battalions are weak, it would be adrisable to consider the Second and Third lines imaginary forces, and that the strength of the Second Line was equal to that of the battalion on parnde; the front this last should attack would then be half the front of the Second line in rank entire, becanse in a Brigade there aro two battalions in the Firing Jine. In the present problem, for war the battalion is 800 strong, but we must deduct losses in the advance, say 50 men, which makes 750 mev, and a battalion of 750 men in rank entire covers 750 paces. As we wish to give the men plenty of room to use their bayonets in the charge, let us add 50 paces to this, which, together with the room obtained by casualties occuring in the charge, ought to bo enough. The front of the Second Line is then 800 paces. 
The Firing Line of the two battalions must then corer 800 paces. If cach battalion sends $2 \frac{1}{2}$ companies into the Firing Line, we shall bave 3 companies in the Firing Line, which in file extended to 3 paces, given a front of 750 paces. Let us make the battalion intervals 20 pacen instead of the 12 laid down in the Field Exercise; adding this to 760 makes 770, which, with four company intervals of 6 paces, namely, 24 paces, makes 794 paces, quite near enough for practical purposes to S00. Fach battalion will have half a company in support some $20 \mathrm{yards}$ in rear of the outer tank, and one company on each flank between this half-company and the Reserve. 'The remainder form the Reserve.

Fach battalion in the Firing Line, then, has its right half-battalion in the Firing Line and Supports, and its left half-battalion in Reserve.

At first sight, the weak part of this formation is the long front, 150 paces, given to each company in the Firing line; but it must be borne in mind that, eren with this front, the company onght to be in hand, as it is all in front of the Captain, who, in the centre of it, is only 75 paces from either flank: 'With' good section leaders, and probably' little smoke and noisc, it ought to be well in control. But as a fact, these fronts are all calculated for the strength with which battalions take the field, and are all too big. It would be Utopian to expect that a Captain, starting on a campaign with $100 \mathrm{men}$ in his company. would lave that number in his ranks on going into action; if, after deducting casualties, be has 70 men, exclusive of non-commis. sioncd oflicers, de., he will be very lucky; the front of 70 men at 3 paces is 105 paces. Even this front is only the front of the com. pany on first forming for attack, whicl must decrease regularly at each adrance.

The third battalion forms.the Sccond Linc, and the fourth battalion tlic Third Linc. We thus have the formation of the Brigale. Whilst passing though the first Zone, the Brigade may be marching in column of route; on debouching from this, probably about the cons. mencement of the second Zone, the battalion commanders will receive orders from the Staff to "form for attack as a right battalion or left battalion." The Brigade-Arajor will show the Commanding Officers the objective point, and the Brigade will extend. Should, howeres, the Brigade pass through the first Zone in line, oi in line of column at deploying intervals, the front of each battalion can bo covered by skirmishers and supports in the ordinary way, cach battalion sending out two companies to skirmish, each company detailing half a company to skirmish and half a company in support. In this case, on the brigade order to "Form for Attack" as a right or left battalion being given, the two compranies sent out by each battalion will form its Firing Inine, other companies being sent out by the battalion to complete the formation. The Brigade, in both cases supposed, would extend to 3 paces, and would adrance by its centre, the left file of the right battalion; this file will not fire, bnt more steadily on the Objective Point, superrised by the sergeant-major of that battalion and the Brigade-NIajor.

The battalion in the Firing Line not directing will march by the Brigade file of direction, its sergeant-major supervising its file of 
direction, under the occasional supervision of the Major commanding its fring line and support; it will be noticed that the order of the companies in the leit half-battalion is reversed, so as to get them in regular rotation in the Firing Line.

The directing battalion will send two siguallers to the Brigade point of direction, and by their means, and signallers between, the Brigade-Major will keep commanication with the General of the Brigarle. A signaller will go with each Captain and keep commanication with the reserve; the bugler will distribnte ammunition. Signallers must bo able to signal lying down.

In the case of a sudden attack by cavalry the Firing Line and the half companies in Support on cach flank, will close on their centres, and throwing back their flanks slightly, receive the caralry in line. If there is time, however, the companies in the Firing Line belonging to No. 1 battalion will closo on their right flank, and those of No. 2 battalion on their left tank. The two companies, one on each flauk in Support, one of whose specinl daties is to watch for cavalry will fire volleys into the flaniss of the cavalry should they attempt to take the firing lipe in flank; should these companies be themselres attacked, they will receive the cavalry in line or square as the Captain thinks best. Any machine-guns with the battalion would probably be pushed well to the flank, also ready to enfilade cavalrs. Tbe reserve will advance, aud as they have a clear field of fire between the Firing Line and themselres, they can fire at the cavalry if they approach.

The brigade will advance thus by its centre, the Firing Line moving like ordinary skirmishers till about the middle of the second zone, when it will probably como under artillery fire. The adrance will now bo by ranks without firing. This will bo continued till tho liring Line becomes exposed to aimed infantry fire, probably about 800 yards from the position, unless the enemy hare thrown out troops in front of their position to hinder the adrance of the artillery of the Attack, when it will be earlier. When the Major in command of the dirceting firing line thinks it necessary, be will gire the order to "Advance by ranks Firing." The directing company will fire first, and when its own flank company gets in line with it the directing company will advance again, and so on. As casualties occur and men drop out, the files keep on closing in towards the file of direction, till they get the ordered interral of two paces, the supnruumerary rank keeping the men in file towards the directing file, but men of different companies will not be mixed, the interval of six paces betreen companies being maintained, no matter bow few men are left in tho company. The supports will reinforce the onter flauk of the firing line by files as room is made, these men moring straight to their front and tonching in towards the file of direction. The Reserve, under the Colonels, would adrance in sach a wny as to be alwass able to reinforce the outer flanks of the Firing Line, seuding its outer company to replace the company in Support, as it adrances to replace the balf-company absorbed into the liring Line. The Colonels would adopt any for- 
mation they chose, so as to lose as fow men as possible: ... They would receive reports by signal as to the nature of the ground from their Majors with the Firing Line.

As all the direction comes from the Brigade point of direction in the centre of the Firing Line, the adrance, by means of the signallers, should be under the complete control of the General of the Brigade. He may wish to signal orders here, as about this time his artillery will probably hare been able to advance within 2,000 yards of the enemy's position, and might assist in the attack. Should the General signal orders, they would easily be carried out, as the mon would be well in hand of their Captains and Colonels.

The adrance will be steadily kept ap till the Firing Line gets within about 450 jards of the Position (see Dingram.2, Plate 3), when the artillery of the attack will probably have advanced again, and got to within 1,200 yards of the position, and the General of the Brigade may wish to give orders, for if the enemy's position is not now well shaken, it would be advisable to crash it by a further artillery fire before the infantry advance nearer. That such is the proper course was shown at the battle of St. Privat, where the Prussian main loss was at some 500 yards from St. Privat; and, again, the Prussian attack on the rillage of $\mathrm{Le}$ Bourget, on the $30 \mathrm{th}$ October, 1870 , gives the same lesson. Should the artillery have to fire over the heads of tho infantry, which they might hare to do in the attack of an Army Corps, as such a mass of artillery corers a very largo front, the infantry will lie down. Unless contrary orders are received, tho infantry will adrance, firing steadily, being reinforced if necessary.

In the attack by a Division or Army Corps, should the Firing Line in its advance, between 500 yards and 50 yards, meet with such resistance as to require reinforcements, the Colonel requiring it will report by signal to the Brigadier, who will order the third battalion, or part of it, to go up from the Second Line. The third battalion will be replaced by the fourth battalion from the Third. Line. Provision for such a change of duties would haro been previously made by the strength of the attack being originally stronger against those points where it is likely such resistance would bo met. Resuming our Brigade attack when the Firing Lino has got to within about 50 yards of the enemy's position (seo Diagram 3), the Colonel of the directing battalion will halt his directing company, and form line and rank entire; the left battalion conforming. Both Colonels will now gire the order for "Independent firing with fixed sights." All this time the Second and Third lines hare been steadily advancing, as shown in Diagram 2, their Colonels taking every adrantage of the ground; and abont the time the Fining line gets to within 50 yards of the Position, the Second Line onght to be within 100 yards of the Firing Line, and whilst the Firing Line is independent firing, the Second Line will form line and rank entire, lying down about 10 jards in rear of the Firing Line, fixing bayonets as they are lying down ready to charge, vide Diagram 3. Should the resistance of the enemy hare been so weak as not to cause the wholo of the Reserves to be absorbed into the Firing Line, the companies of the Reserves overlapping the Second Line will 
closely follow the flauks of the Second Line in its charge. I think it is one of the adrantages of an attack on theso lines that it permits this to be done, and thus allows a drill in the Attack Formation to be carried out in peace-time, without necessitating the large number of casualties falling out, as in the Field Exercise attack.

Practising losses in moderation may bo good, but I doubt the wisdom of the present plan of simulating such largo losses, for what must pass in the mind of a young soldier as he lies on the ground, himself a casualty, and two or three hundred like cases round him $?$ The sceno must make an impression on his young mind, which could not.be so favourable as that of hunting on the mind of Mr. Jorrocks, when bo gare utterance to the celebrated remark that "Hunting was the image of war with only 5 percent. of its danger." Young soldiers cannot bo inspired with confidence by sach a scene, and it must bo much moro calculated to mako them what a sportsman would term a bit "gunshy.".

The remainder of the attack would be conducted as laid down in the Field Erercise, except that, in re-forming, the companies will each consist of their own men, and be in the regular rotation.

- The attack formation for a battalion is tho sane as that shown in this Brigade attack, the battalion acting cither as a right or left battalion.

\section{The Company.}

A form for attack for a company could easily bo giren on tho same principles as those of a Brigade or a battalion, but a company is too small a unit to attack by itself. Its practice for the attack formation should consist of being thoroughly trained in its principal requireznents, viz., in skirmishing, the adranco by ranks, reinforcing, and the adranco by ranks firing.

\section{The Army Corps or Division.}

In the attack by an army corps or division there will probably be two or more objectire points, against each of which a dirision or brigade would bo detailed.

Should, however, the army corps or division hare only one objective point, and the attack be a long, continuous one, it will be conducted in exactly the same way as that giren for a brigado acting by itself.

'There will be one Directing Point, army corps, or dirision, as the case may be. The battalions on the right of this Directing Point will form for attack as the right battalion of a brigade; the battalions on the left of it as the left battalion of a brigade. In such a case, the supports of all battalions, except those of the two extreme flank battalions, will follow behind the battalion interral next their outer flank companies.

The strength of the troops opposite points whero resistance is likely to be met will be increased by taking troops away" from those points where there will be little resistance. 
Colonel SLADB : I propose, Sir, with your permiesion and that of the mceting, to say a rery few words on the interesting lecture that we hare heard, and that in no hostile spirit. In the opening sentenec of the lecture, Cólonel Yrior stated that tho preeent attack formation $\mathrm{mas}$ " rirtually dead." In that casc it occms to me thas it is rather like flogging a dead horse to go on attacking a formation which in virtunlly dead. - Without going into details, the msin point of his lecture was that he proposes a new attack formation. Now it acems to me very doubtful whether he is on the right tack in proposing a new attack formation. It may be that the present attack formation is rirtunlly dead; whether it should be replaced by another is a rers different point. The Germane, who are after all rery practical soldiers and hare the experience of a great European war to guide them, hare not only refused in their latest drill regulations to laj down ang normal ordes of attack, but hare positircly forbidden it. They eay that in war circumstances are alsay rarying, and that the letter kills the spirit, and that the responsibility thrown upon Officcrs only brings out tleic better qualitice, and therefore thes utteriy refure to lay down uny normal order of attack. I should 885 it is rery posible when our new Drill Book cones out you will find that "attack formation" has gone by the board and will not be replaced, but we shall act in the same spirit, and as the Germans say, we will not have any normal order of attack; we will trust the Offeers to carry out the attack according to the nature of the ground, and the position of the enemy in the best way thes can, and according as they have been trained in peace-tiune; and that $I$ beliere to be the true spirit of the attack. After all, in our own present Regulations, though there is a normal order of attack it is dis. tinctly laid clown that that is not to be the guide under all circumstances, but it is merely giren as an example of how, perhaps, best to carry out an attack under cerfain conditions. With regard to details, I should rery much doubt whether at 60 jards from the cnemy's position any battalion could then be trusted to go through any sort of mancurre like forming into single rank and forming into line. I fancy when you come to within that distance, or angthing approaching it, a halt would be futal; the eole object will be to push on. Some Continental Powers in theip latest regulations hare introduced an "attack fire," i.e., firing on the more. When they get within 300 jards the rifle is licld at the hip and they go on and on firing, knowing perfectly well that at these short distances aiming and halting are all gone by the board; the only thing Jou can do is to push on and on, and I beliere that will be the spirit of our new Regulations when thes come out.

Captain H. L. Prkixctos (21st Iussars) : I should like to be allowed to sas a word on the second factor which the lecturer lajs down as neccsiry in considering au infantry attack formation. That fuctor is "the employment of caralry in masses." I would rather substitute for that expression a wider onc-" the emplos. ment of caralry to check attacking infantry. The lecturer has admitted that the attack of caralry on attacking infantry is a matter which unust be considered; but, where he first deals with it, lie appears to treat the matter rather lightls. "The subject," he eays, "is a decply engrossing caralrs oue, but in considering any attack formation we cannot criter further into it than to take it into our calcula. tions as a possibility, and as such to nole our plans beforchand against it. I renture to think the experience of recent wars and the increase of cavalrs which is now being made in most Continental armies justify the belief that the use of caralry to check attacking infantry will be of pretty frequent occurrence in the wars of the future. And I fail to see why that attack should be limited to carnlry "in masses." If it is possible for large bodics of caralry to break through the infuntry-fighting line. I think it will be also possible for emall bodics, at any rate under farourable conditions, to breal through; for the real resistance to a body of caralry attacking an infantry line is the amount of fre which can be brought to bear upon it, and that is practically regulated by the number of rifles in or close to its line of adrance. And I would point out that the true role of caralrs, employed in the manner indi. cated, appears to begin after it las broken througle the firing line, and is at liberty to play haroe witl the.ritals of the dirision or brigade it is nttacking, the internal fractions of which would be paralysed, unable to fire, unable to use the most effectire means they posscss of resisting caralry, on account of the danger of doing more damage to one another than to the enewy. It will therefore be, I thiuk, in any 
plan of attack necessary in future to provido against an onelaught of caralry as a probability rather than as a possibility merely, and to regard it as of prime importance to prevent caralry breaking through the firing line. Now, from a caralry coldier's point of rier, the old formation in groups of four infantry soldiers, into which the firing line is supposed to fall to resist caralry, is certeinly an cary ono to attack-particularly casy if tho object of the caralry is considered to be getting through the firing line-passing through it rather than breaking through it, and getting to work upon the detnched portions of the division or brigade which lic belind that line. It appears to me that the formation proposed by the lecturer would, from this point of riew, be cren more adrantagcous to atticking caralry then the old one, for not only would the intervals between the compuny squares which he proposes to form be wider and admit larger bodies than the interrals between the old groups of four, but the formation of compeny equares rould neccssarily take a longer time than the formation of groups of four, and that time would be the few moments during which the cavalry is advancing under close fire, the few moments in fact in which the infantry might, if not entering into the new formation, make their fire tell with the greatest effect upon the attacking caralry. of course it is too much to espect of ans infantrs that they will reccirc caralry in single rank with considerable intervals between the man and man; but I doubt if it is crpecting more than is crpected of caralry ordered to attack them, and I beliere any curalry Oflicer leading a squadron or a line against infantry would consider the ordinary formation known as rank cntire-cach unan rcnmining on his own ground and guarding a front of about tiro paces-a more difficult formation to attack other than cither the old groups of four or the company squares now pro posed by the lectures. I would, therefore, submit that the proper formation for the firing line, when attacked by caralry, is "rank entire," reinforeed, if necessary, from the supports.

Licut.-Colonel JI. J. IIIXG-HARMAX: I must congratulate the lecturcr upon haring dealt in a rery able manner with a very difficuit subject. I an glad to hear fron hin that the present attack formation is now considered as dead; Colonel Slade has also told us the same thing. Colonel Prior has already dealt with the bad points of the system, so that there is no necd to refer to it any norc. I think with reference to an attack formation there are other points to be considered besides those that hare been put forwarl. There is the nature of the ground oreswhich we lare to attack, and the people we hase occupsing those positions. For instance, to make an attack upon a disciplined enemy entrenched on lerel or undulating ground is a rery different thing to attacking a foree of undisciplined but warlike Asiatics strongly posted amongst rugged aud steep hills, and so on : therefore, in following out one fised plan we should rery likels come to gricf; especially if for the purpose of attacking an encmy on a hill we adoptcd the attack suited for lerel ground. I ain atrongly of opinion that it is very much better to practise a great many different forms of attack and to let erery Commanding Officer go his. orn way to work. I think that is the plan now to be allowed on the Continent. I think the plin proposed by Colonel Prior has considerable adrantages. It keeps the whole bittalion together; it keeps the command of companies and the command of regiments more together than the present system, and therefore therc is a good deal to commend, although as soon as the attack is launched, eren iu that formation, it $i s$ rather loose, the sane as in the prescnt onc. The lecturer spote of the probalility of our haring to attack uncirilized troops, but it secms to me that is what we are alceays doing, and we must adapt our formations to mect the rarsing circumstances which are inscparable from such kinds. of warfare. With regard to the adrance in the attack formation, a grcat deal is said about the "compiny of direction." I think when jou get within 450 jards of any place the "company of direction" will not be taken much notice of by anjbody; it will just be a casc of go as hard as erer you can. It does not then inatterwhat formation you are in, whether you are going upon the present system, or upon this proposed system; as regards the pace of the company of dircction, Jou go as hard as crer you can, and your fire will be as liard as jou can fire, or not firin: at all. If you are fring from the bip, the running fire the first spealer spoke of just now, it will be rery much, I take it, what it used to be the case in the old dass 
when wo had smootl-borcs firing from the hip; and $I$ think if you attack in an formation jou will find the came thing, that it would go by itsclf; certainly when once the attack is launched, the power of the Commanding Officer is gone. sloould liko to aco certain formations of attack forbidden, ratlicr than certuin ono suthorized : but those that are authorized should be auited to the charscterietics of the troops emplosed, to the British troops and tho natire troops of the Indian Arms working in tho same line with English troops. You would find that jou would get probably a s5stcm of advancing bs ranks, or by groups, or bs four-deep formationt, or something of that sort, and they would lend themsclves much more to tho charsetcristics of our eoldiers, and jou nould get a much better command by tho Oflecs. Then, when an attack is ordered by a brigado or a dirieion, as soon the object of attack is pointed out, let erery Commanding Ofticer put his regiment in whaterer formation lic plasses. There need be no fear of one regiment beine behind another, the pace will be just as hot 29 erer they can all malic it ; and think in tho same way with inspections ; that General Offeers ehould point out positions to be attacked, and the Commanding Oflicer should tako up any forma. tion ho pleases, and let him be reported on accordingly. It he adopts a good ssstem and rorks his men accorlingly, in a fornution suitablo to tho ground, ho should be well reported on; but jou should not restrict him to one normal formation. I hare eccn men ruuning about ou the eands of tho sca shore throwing themsel pee flat on their stonachs, and doing all sorts of things which could not posibly be clone if they were opposed to an enems, or if thes were doing it on hilly ground, practising in peaco what they could not do in war, which is foolish. If, as has been stated, it is rery likely that the new Drill Book will do away nitl ang normal for nutions to be used in the attack, I think it will be an excecuingly good thing. At the same time, I thiuk Colond I'rior has done rery good serrice in bringing forwand his lecture to-day.

Captain O'Carcaarax: I risc to usk a question which has been suggested to me by what I hare seen on the black-board with reference to noiscless powder, and I find also mentioned in the lecture a powder which sliould give little noise. Nor, I hare not as jet ecen a particle of eridence to shor that we have, or that we are likely to have, any means of propelling bullets without explosion, and any explosion withont noise. Another point I noticed was that the lecturer said that in certain cases the men should open out so as to gire them room to use their bayonets. But did he not consider that, the more room you gire the men, the more bayonets they hare opposed to them; for, if a man lias a grcat deal of room to use his bajonet, he will hare to use it against a great number of men if thes are in close formation? With regard to firing from the hip, I may mention that I tricd that very carefully nt a rille range, and the result of my practice, and that of sercral otlier men, on that occasion was this: I was the only one that hit the target at all. I fircd at a target at 200 yards, but it was onls after tuking about two or three minutes cach time to estimste the cleration of the rifle that $I$ could hit it, and then I was often very far wrong in eleration, so that I am led to beliere that firing from the hip, ercept at a few yards' distance, would be almost innocuous.

Major Fuviad Pariser: There are tro points that Colonel Prior has mentioned which I thought rather important: one was that the ranks should not be close together on account of the penetrating power of the new rille bullets with swokeles 3 powder, and the other was that lie pointed out the advantage of lying down on account of the low trajectory of the projectiles. The penctrating powor of the new rille $I$ hare tried, and it is from 11 to 121 -inch deal boards placed 12 inches apart. 'The bullet inrariably, I mas say, gocs. through 11 such boards, and sometimes it penetrates 12, that is, with swokeless powder. Hence, if the ranks are close, it would lead to screral men being struck. The next point is that of lying down to aroid the effect of low trajectory. I was rery interested in

I I m entirely opposed to the system of allowing the rank and file to get into the way of falling out oo 29 to represcut castualtics; that kind of instruction should be confined to Oficers and section coumanders only, and no one clse should crer be allowed to do such a thing. 
realing a short time ago an article in the "United Serrico Magazine" for 1841. It. was the account of an eje-witness, at Oficer of the 1st Rosals, which regimont wse in Picton's Dirigion. When the French brought forward-their reserro urtillery (12-pounders), at a distance of 400 sards, to batter Picton's division bcfore the grcat assault of D'Erlon's Corps, the French Artillers Offecrs found that at that range, with their long 12-pounders, the trajectory was so flat that the shot pasecd orer the British troops who were lying down. They accordingly abandoned the shot firc, and took to grape. These projectiles descended on the Dirision, killing and wounding a great many men. The cscape of our troops on this occasion from round shot prores, as Colonel Prior pointed out, tho necessity for soldicrs to tako crers opportunity to aroid Alat trajectory of projectiles by lying down when they can.

Licut.-Colonel E. GoxTER: As no othẹ Oflicer secms inclined to rise, I should like to say a fem words. I thiuk all Oficers who talic an interest in the tactics of the day are more or less united in opposing the normal attack formation. It is a bugbear. I think thero is a general fecling that there should be no form for attack laid down in detail, but that certain fixed genernl principles should be laid down for its conduct. Is, howerer, Colonel Prior thinks a normal attack elould be cstablished, and proposes an improsed one, wo must consider whether it has any great adrutages orer the established ouc. I think his point is that his attack is more suited to the characteristies of the British troops. I hare not lod time to look into the matter beforcband, $s 0$ as to be able to criticize it in detail, but there are one or two points I should like to touch on. I may hare misunderstood Colonel Prior, becuuse it takes some little time to thoroughly grasp all the complicated busincss of such an attack formation; but, with regard to the conduct of the infintry of the first line when attacked by caralry; this is a matter of principle. In common with a great many infantry Officers, I object to the idei that when coralry attack infantry the latter must of necessity form squares, whether large or small. I think well-trained, courageous infantry can always receire the attack of carairy in line, as we are taught, eren when not exactly shoulder to sloulder. In the Franco-Gennan War (I think it was at Sedan) the Prussinn troops receired and repulsed the gallant attacks of the French cavalry, not in squares but in line, or ns they were. Why should not British troops do the same? If, as been ably pointed out by a caralry Ofilicer, the infantry aro to be fussed about and got into squares, while tho caralry are closing on them, the caralsy will hare a much better chance than if the infuntry simply remain steady and receire them in whaterer formation they liappen to be: Sup. posing, howerer, these squares to bare been formed. Colonel Prior eass the caralry charging through the gaps thus formed in the firing line would receire the fire of its reserves firing through this gap. All I can say is, I should not like to be in the firing line then. It is one thing to be shot by jour enemies, You expect that, but it is rery uncomfortable being shot by your own men. The proposed formation seems simple and sfmmetrical, and it might be carricd out on cren ground, but I slould think it would be diffeult when the ground is broken. As Coloncl King. Harman has pointed out, I do not think it possible to muke any chinge of formation under close fire, and lying down, firing bisoncts, \&c., within 50 jards of the cncms, rould, I think, be impossible. Colonel l'rior las laid stress upon the fact that in future there will be no emoke, and that, therefore, his proposed attack can be casily carricd out. We must, howerer, bear in mind that the German and other uations are muling cxperiments with a ricw of creating smoke, and I think we elall find that the attackers will hare to create smoke somehow before they can hope to push on their ndrance. With regard to firing from tho hip, which Coloacl Slade las mentioncd as being re-iutroduecd by the French, I lope we shall not follow their crample. I nm aware that there hare been instances where on emergenes such a plan las been adopted. In the Mutiny (I think at Iucknow) a fer men, about to charge, fired a rolley from the hip, and this was so unexpected that it bad a. great moral effect on tho enemy, and the charge was successful, but, I trust the practico will not become general, for, as has been pointed out, the effect is almost alwags nil. Whether we have a normal attack formation, or mhether it is abandoned, I trust we shall always endearour to keep our men as cool as yossible, remembering after all that it is fire, not formation, that 
wins the battle. Accurate and cflicient fire is the main point, and men cansot delirer that accurate and efficient fire unless they keep.cool. Frery cffort should, therefore, I think, be made to attain this, and we ouglit not to abandon all hope of doing so until the last poseible moment, until what may be called "the Donnybrool moment," arrires.

Licut.-General J. H. Dexse: What has becn said by Colonel Gunter and othere brings me on my legs. For the last twenty-fire years I hare had the prisilege of commanding buttalions, brigades, and divisions in those rarious and innumerable systems of attack which are being continually invented by diferent Officers. I am not going to enter into any question as to whether the lecturcr's attack is better or worec, but I do hold that there must and ought to be some light skctchy mobile attack laid down, and bept up still in our Drill Book, for, from my comparatively long experience of the many Commanding Ollicers I hare inct, it is all rers well to suy. "Icaro" it to crery Commanding Officer to use his own discretion; but I belicre that diecretion rery often would result in confusion. Fach Commanding Officer, or many Commanding Officers, would insist upon introducing some peculiar faddigh mode of their own. The conscquence mould be that in a large number of troope there would be no unity of action, cren in mancerring in times of peace, and I very much doubt whether there would be in actual war unless there was a certain amount of principle laid dorn for making an attack, bringing up the reserres, and opening fire. I am not going for one moment to confine people to exact wass. In crersthing else cxecpt this point I entirely agrec with Colonel Slade, with whom I hare had the honour of serring in a great nany attacks, but I renture still to maintain that some skctcly normal system should ulways continue to be laid down for those attacks. Coloncl Gunter said he did not beliero it was erer necesiary for attacking infantry in lino of skirmishing attack to form into cither groups or squarcs to mect the attacks of carnlry, in inany of our little wars, in Aldershot and the Curragh, and rarious places. All $I$ can say is I hare myself been in command on one orcision of a troop of the 3rd Dragoon Guards when three companies of infantry were put out of action nt once by Sir Arthur IIerbert, as Umpire. I had the troop of the 3rd Dragoon Guards hidden behind a lime-kiln, where noboly could see them, and they were launched so suddenly and at such a pace on the flank of the infantry that that infantry must hare been entirels swejt down the whole length of its line, if they had not got, at all crents, into some sort of equare. Only a few moments clapsed before the caralry were upon them, and how in the world can infantry form line against caralry attacking on the flank in that manner? It would be impossible; if the cavalry wcre quick they must smash them up. Only two scars ago, on the For Ifills, I was out with the 10th IIussars. It was a time nttuck; if myopponents did not get up to my position and were not able to drire me from that position by a certain timc, I won the das. I had squadrons and troops, cren of the 10th, hidden where thicre ras undulating ground, on tho flanks of the attack of infantry, and by so doing, I orer and orer again, nnd by my husear lcader's charging in a sclf-sacrificing epirit, forced the infantry to etop, and form eitlier equares or groups, and then peppered them with horse artillery. By that means I continually delajed the attuck, so that at last the General gare it in iny farour.

Colonel PRIOR, in reply : I thank you all rery much for jour kindness in coming here to-day, when I do not know low many things are going on, and I am much obliged to sou for your presence. Colonel slade remarked on my haring said that the formations were "rirtually dead." Well, the dificults of a lecturer is that be must hare something to hang his hat on. He must hare some foundation to go upon, and, as the Ficld Excrcise formations are being altered, I say they are rirtunlly dead, because $I$ hear rery often in the clubs the question asked, "What will happen as to the Field Escrcise formation?" and the ansker is that it will right itself in war. What docs that mean? It will right itself at the expense of thousands of men. Colonel Slade eaid that, if I thought the formation dead. What was the use of my flogging a dead horse? Well, I think in a case of that sort, if a loorse is dend, and Jou think him a bad one, the best thing you can do is to disscet him, and find out his bad points, aud that is what I have humbly tried to do. I licar a great wany abuscs of the old cxcrcisc formations, and I hare tricd to test them like a 
chenical analysis by test 3 laid down in tho Ficld Excrcisc. My object lias been to try and get any little good that we can out of a formation; cren, if it be dead, to try and male use of it. Another Oficer spole as to forming line at 50 jards. It is about 50 jards; but of course jou cannot lay it down as such, and, as has been said, it would be perfectly absurd to attempt to form line at 50 jards, if you had a wellformed cneiny in thint position rendy to meet you. In such a case what would be the use of falling in line 50 yards? I rery much depend upon the use of artillery in the attack, and I especially said that, at 450 jards from tho enemy's formation, it is especially necessary for the Ceneral to notice if the encmy are sufficiently cruslied in that position to allow his infantry to adrance, and I think any General would be rery foolish to attempt to get near a position of that sort, unless he har thoroughly well erushed them by fire. When that is done, and he has ordered his adrance, I think the plan submitted here of getting closer is better than the one litid dorn in the Field Exercise, in which it sajs, "When the eccond line"-that is the assaulting line-" gets to 400 yards from the position"-I assume thes go along at a pretty good pace-"the firing lino will procecd and describe Section 22, No. 11." Scction 22, No. 11, sajs, "On-arriving at, sas, 150 yards from the position, the Captain will gire the caution for independent firing." 'Therefore, by the Drill Book, the independent firing commenes at 150 jards from the position. "At the time the assaulting line commences firing independently, tho sccond line will more forwarl at a steads double." At 150 yards those men are to double with fircd basouets under fire, and at the end of that they are supposed to use their bajoncts. I should think, in such a case, they would be very much blown. If you want men to assault a position you must get them mucl closcr than 150 jards, if they aro to be of any good to use their buyonets. Another Oflicer said the employ. ment of caralry would bo mucl more frequent in future wars than had been the case formerly. If that is so, I think we liare all the more reason for taling steps to guarl against that danger, and I think, if Jou hare men well under the command of their Captains, they hare much more chance of resisting a caralry attack. I have sliown in the first diagram, representing an attack at a fistance of 1,000 rarts from the position, the front company as $100 \mathrm{y}$ reds long, 200 yards deep, and in three different lines-the firing line and two support3. In the formation submitted on Dianraun 4 on the wall the line is 100 jards. Now, which company could aasemble quickest to resist caralry? Then fring from the hip has been mentioned. I hare quoted Prinec Fraft, a man who has ecen more actual serrice than anjone clsc. I hare read out to jou his remarks on the dificults of stopping infantry firing, cren when it is a steidy fire well under command. Ue says the men like to licar the rattle of their rifles, and that is perfectly true. Now, when it is so difficult to stop fring, as Prince Kraft sass, when the company is well under control, how much more difficult will it be when you hare men running along with their rifles firing at the double? Tou will nerer stop them at all. Noiseless powder has also been referred to; of course I do not know whether there is to be noiseless powder, but ererybody scems to think so. There is to be a smokeless powder, and, probably, a noiseless one; they all think so, but, at all crents, so far as the argument goes, it would bc much unore difficult for troops in the Field Exercise fornation to aftack where there was smoke than without, because in that formation cach company adranced by its centrc, and you really haro sisteen lines of adrance. If there is smoke, how can the non-commissioned officer behind the centre of each company dircet the adrance? How arc they all to adrance, going to the same point? Thes would bo all orer the place. The danger of ranks firing at oue another is, I think, prored by Major Pulliser, when he says that it lias been found, by trial, that the new bullet will go through twclre deal boards, each an inch thick, and at some distance from cach other. It is quite possible with men 100 yards apart from one another, for a bullet, if it does not hit a bone, to go through two or three men. 'This shows the danger of having troops behind ono another. $\Lambda$ s to tho argument of laring no normal formation, I think that has been disposed of by Gencral Dunne, and I necl not go into it. I think he has so plainly sliokn the adrantage of haring some eort of formation, that nothing more is necessary. When you hare largo bodicz of men together you must hare fixed rules, and those rules must hare fixed points. I say jou inust hare some normal attack, not a fixed point; but let us liarc iudependent 
attack on sinall points. Onc Officer remarked that, with troops in this formation, he should be very sorry to be in the firing line, while the scserres were ehooting through the gape. I Im nfraid I did not quite explain the circumstances of that case. I said it was only when the firing line collected on its flank. "The ider was that, if the caralry attacked this boly on its right, and that body on its left, the wholo front is 800 paces, and there is $110 \mathrm{gap}$, becausc cach of the battalions corers 400 paces. The front of the two companies shown in the diagram would be 100 files, 100 paces on ench flank. 'Therefore, you would hare 600 paces of open space, through which the reserres would fire at the caralry adrancing, and with smokeless powder and a smokeless field, I do not sce why the firing linc could not concentrate on cach flank, so that, as soine of the spcakers hiare said, the caralry should be reccired in line. The whole essence of this attack is that they slould $b$ e reccired in line. The infuntry concentrate on their centres. I haro nothing further to add, but I am rery much obliged to you for your bind attention.

The Charrsax: At this late hour of the erening, particularly as this is a matter. rery much out of my experience nt present, I do not intend to detain the mecting. I think that the rery fact of Colonel Prior's having taken exception to what is cstablished, und liaring proposed something in the place of it, is descrring of prisise, because I find the tendencs of the present das is to take exception to crersthing and nerer to propose anything to replace it. Certainly I think great credit and prise is due to any Officer who will do as Colonel Prior has done, and I wish there were more who came forward lecre and laid down their riews with something like precision. There are tro points which I may adrert to, and those aro the great charges of the French caralry that he spoke of, first at Worth and afterwards at Sedan. Scdan I sáw with my orn eyes, Wörth I dicl not, because they all took place at a rery considerable distance from where I was on the field, and the one of which I Eaw the after traces round the corner of a hill. On the nert day I rodo poet the rillage of MForsbronn, a small lianlet near which it took place, and I suppose a wilder and more insane attack was nercr made in this morld. There were two regiments of cuirassiers, and two squadrons of lancers. They attacked througl rinejards, about the most difficult place that caralrs could pass through, and they attacked troops who were posted in houses and behind garden walls, in fact in as sccure a position as infantry could well be in, and their fate was simple destruction; a more terrible sight I nerer witnessed than that which I rode through the next day. Though the men had been mostly remored, the desd horses, and arms and saddlery were all lying about, showing what the effect of the infantrs firc had been. The attack at Sedan reminded me of nn old story connected with the battle of Talarers. The attack at Sedan took place orer most unfarourable ground. The men were most gallantly led, magnifeently led; it took place trice: I am not sure if it was not three times. There was a dip almost amounting to a small rarine in the ground, into which the caralry fell, and as thoy emerged on the other side of it they nere shot down by the troops, the companics chiefy in support of the artillers. It was much the same at Tularera, where in a charge that took place one of our regiments came to very serere grief. Old Arentschild, who comznanded a German regiment in support, on bcing told to charge orer the ground caid, "I rill not bill my young mans," and he entirely declined to charge. In that case there was also a rarine, into which the reginent, I do not remember which it was, fell on charging. I think we ought to be rers much obliged to Coloncl Prior, more especislis as he has not a great deal of time on his hands. He lcares us to-morrow for a post in which $I$ hope lic will pass I do not know how many ycars, before he will rant out of it, but pase as happy years as I passed there fifty jears ngo. I think it is the best of quarters : certainly it used to be in my tine-dcar old Gibraltar-and I call upon you unanimously to wish him licalth and happiness in his new sphere of action. 